\title{
ANALISIS USAHA JUAL BELI KAMBING DI KELURAHAN TEMBILAHAN KOTA KECAMATAN TEMBILAHAN
}

\author{
Yuslizar $^{1}$, Gunawan Syahrantau ${ }^{2}$ \\ ${ }^{1,2}$ Program Studi Agribisnis Fakultas Pertanian UNISI \\ e-mail:.1 faaiq2011@gmail.com, ${ }^{2}$ syahrantaugunawan@gmail.com
}

\begin{abstract}
ABSTRAK
Meningkatnya permintaan terhadap produk peternakan menyebabkan peningkatan pendapatan masyarakat. Salah-satu jenis ternak yang cukup potensial untuk dikembangkan adalah ternak kambing. Ternak Kambing di Kabupaten Indragiri Hilir sudah cukup dikenal oleh masyarakat yang dapat dijadikan sebagai sumber pendapatan tambahan dalam usahatani terutama di daerah pedesaan. Berdasarkan data dari Badan Pusat Statistik Kabupaten Indragiri Hilir Tahun 2018, potensi usaha peternakan untuk daging $\pm 45 \%$, maka peluang potensi pengembangan usaha kambing di Tembilahan Kota sangat potensial dilihat dari permintaan lebih besar dari ketersediaan yang ada. Namun yang menjadi permasalahan adalah banyak para peternak belum mengetahui seberapa besar efesiensi usaha tersebut, kemudian tidak tercatat dengan baiknya biaya yang telah dikeluarkan. Metode yang digunakan dalam penelitian ini adalah survey. Metode analisis yang digunakan adalah : (1) pendapatan usaha, (2) efesiensi usaha. Hasil penelitian menunjukkan bahwa : (1) rata-rata keuntungan yang diperoleh adalah sebesar Rp. 8.370.412,00 per produksi, (2) Nilai RCR adalah sebesar 1,12 yang berarti usaha jual beli kambing efesien.
\end{abstract}

Kata Kunci: Peternakan, Pendapatan, Potensial

\section{ABSTRACT}

Increase demand for products. One type of livestock that is quite potential to be developed is goat livestock. Goat cattle in Indragiri Hilir Regency are well known by the community which can be used as a source of additional income in a special farm in rural areas. Based on data from the Central Statistics Agency of Indragiri Hilir Regency in 2015, the potential for livestock farming for meat is $\pm 45 \%$, then the potential opportunities for developing goat businesses in Tembilahan City are very potential to be seen. However, what is contradictory is that most farmers who do not yet know how much business efficiency is, are then not approved by the costs incurred. The method used in this research is survey. The analytical methods used are: (1) operating income, (2) business efficiency. The results showed that: (1) the average profit gained was $R p$. 8,370,412.00 per production, (2) The RCR value is 1.12, which means an efficient business of buying and selling goats.

Keywords : Animal husbandry, Income, Potential

\section{PENDAHULUAN}

$\begin{array}{cc}\text { Meningkatnya } & \text { permintaan } \\ \text { terhadap produk } & \text { peternakan }\end{array}$

menyebabkan peningkatan pendapatan masyarakat (Hamarong, 2014). Salahsatu jenis ternak yang cukup potensial 
untuk dikembangkan adalah ternak kambing. Namun peranan ternak kambing di Indonesia sebagai penghasil daging dalam menunjang penyediaan kebutuhan daging nasional masih rendah, tidak lebih dari 5\% dari komponen kebutuhan daging yang ada (Haryanto dkk, 1997). Meskipun demikian ternak kambing merupakan komponen penting dalam usaha tani rakyat karena pemeliharaan kambing dapat membantu subsistensi ekonomi rakyat dengan pemanfaatan sumber daya alam yang tersedia disekitar.

Kambing merupakan ternak ruminansia kecil yang relatif mudah dipelihara dan dapat memakan berbagai hijauan terutama terhadap daun-daun muda. Kambing dapat hidup menyesuaikan diri pada daerah ternak lain sukar hidup seperti didaerah batubatuan, daerah perbukitan atau daerah pegunungan (Middatul, 2010).

Kambing tersebar luas di daerah pedesaan dan biasanya dipelihara dengan tujuan sebagai tabungan hidup maupun sebagai ternak potong/ternak susu untuk dikonsumsi keluarga disamping kotorannya dapat dipergunakan untuk pupuk yang baik bagi tanaman. Pemeliharaan ternak ini di pedesaan merupakan bagian dari usaha tani secara keseluruhan dalam skala yang relatif kecil dengan rataan jumlah kepemilikan sebanyak 3-5 ekor/keluarga petani. Menurut Krisna dan Harry (2014), Tingkat kepemilikan ternak merupakan banyaknya jumlah ternak yang dipelihara oleh petani ternak atau diusahakan dalam satu kali periode pemeliharaan. Keadaan ini membuktikan bahwa ternak kambing belum mendapatkan perhatian yang besar dalam hal peningkatan potensinya sebagai pemasok daging untuk dapat ditingkatkan kepada skala produksi yang secara ekonomik memberikan keuntungan yang optimal (Hermawan, 2009).

Usaha ternak kambing sudah saatnya dijadikan usaha pokok, karena kambing relatif cepat berkembang biak dan merupakan salah satu jenis ternak yang akrab dengan sistem usaha tani di pedesaan. Hampir setiap rumah tangga memelihara kambing. Sebagian dari mereka menjadikannya sebagai salah satu sumber penghasilan keluarga. Saat ini pemeliharaan kambing bukan hanya di pedesaan, tetapi sudah menyebar ke berbagai tempat karena semakin banyaknya peternak kambing yang muncul disebabkan oleh permintaan daging dan susu kambing yang terus mengalami peningkatan (Sarwono, 2007).

Berdasarkan data dari Badan Pusat Statistik Kabupaten Indragiri Hilir Tahun 2018, potensi lahan yang dapat dikembangkan untuk usaha sub sektor peternakan seluas $\pm 225.863 \mathrm{Ha}$. Jumlah populasi ternak kambing 27.151 ekor, sedangkan untuk kebutuhan daging di Kabupaten Indragiri Hilir \pm 2.995.744 ton. Yang mampu dihasilkan usaha peternakan untuk daging $\pm 45 \%$, maka peluang potensi pengembangan usaha kambing di Kelurahan Tembilahan Kota sangat potensial dilihat dari permintaan lebih besar dari ketersediaan yang ada. Namun yang menjadi permasalahan adalah banyak para peternak belum mengetahui seberapa besar efesiensi usaha tersebut, kemudian tidak tercatat dengan baiknya biaya yang telah dikeluarkan.

Berdasarkan latar belakang tersebut tujuan penelitian ini adalah untuk mengetahui keuntungan dan efisiensi usaha jual beli kambing di Kelurahan Tembilahan Kota. 


\section{METODOLOGI PENELITIAN}

\subsection{Tempat dan Waktu Penelitian}

Penelitian ini dilakukan di Keluarahan Tembilahan Kota Kecamatan Tembilahan Kabupaten Indragiri Hilir yang ditentukan secara purposive. Hal ini dikarenakan di Tembilahan Kota tersebut banyak populasi ternak kambing. Penelitian ini dilakukan pada bulan Mei 2020

\subsection{Metode Analisis Data}

1. Biaya

$$
\mathbf{T C}=\mathbf{F C}+\mathrm{VC}
$$

Dimana :

$$
\begin{aligned}
\mathrm{TC}= & \text { Biaya }(\mathrm{Rp} / \text { Produksi }) \\
\mathrm{FC}= & \text { Biaya Tetap (Fixed Cost) } \\
& (\text { Rp/Produksi) } \\
\mathrm{VC}= & \text { Biaya tidak Tetap (Variabel cost }) \\
& (\text { Rp/Produksi) }
\end{aligned}
$$

2. Pendapatan

$$
\mathbf{T R}=\mathbf{P} \times \mathbf{Q}
$$

Keterangan :

$\mathrm{TR}=$ Pendapatan usaha ternak (Rp/Produksi)

$\mathrm{P}=$ Harga ternak (Rp/ekor)

$\mathrm{Q}=$ Jumlah ternak (ekor)

3. Pendapatan Kerja Keluarga

Menurut Hernanto (1991), yaitu :

PKK $=\boldsymbol{\pi}+$ TKDK + D

Keterangan :

PKK = Pendapatan kerja keluarga (Rp/Produksi)

$\pi=$ Pendapatan bersih (Rp/Produksi)

TKDK = Upah tenaga kerja dalam keluarga (Rp/Produksi)

$\mathrm{D}=$ Penyusutan alat (Rp/Produksi)

4. Penyusutan Alat

Menurut Sinuraya (1985).

$$
\mathbf{D}=\frac{\mathbf{C}-\mathbf{S V}}{\mathbf{U L}}
$$

Dimana :

$\mathrm{D}=$ Nilai penyusutan alat (Rp/unit)

$\mathrm{C}=$ Harga beli alat (Rp/unit)
$\mathrm{SV}=$ Nilai sisa alat (Rp/unit) (diperoleh $20 \%$ dari nilai beli alat)

$\mathrm{UL}=$ Masa pakai alat (tahun)

5. Keuntugan

$$
\pi=\mathbf{T R}-\mathbf{T C}
$$

Dimana :

$\pi=$ Keuntungan usaha (Rp/Produksi)

$\mathrm{TR}=$ Total pendapatan (Rp/Produksi)

$\mathrm{TC}=$ Total biaya $(\mathrm{Rp} /$ Produksi $)$

6. Efisensi

RCR = TR/TC

Dimana :

$\mathrm{RCR}=\quad$ Efisiensi

$\mathrm{TR}=$ penerimaan $(\mathrm{Rp} /$ Produksi $)$

$\mathrm{TC}=$ biaya $(\mathrm{Rp} /$ Produksi $)$

Ketentuan :

Jika R/C > 1 maka layak untuk dikembangkan.

Jika $\mathrm{R} / \mathrm{C}<1$ maka tidak layak untuk dikembangkan

Jika $\mathrm{R} / \mathrm{C}=1$ maka berada pada titik impas

\section{III.HASIL DAN PEMBAHASAN}

Usaha pemeliharaan kambing di Kelurahan Tembilahhan Kota tidak dilepas melainkan dipelihara di dalam kandang. Sebelum melakukan usaha kambing, terlebih dahulu peternak mempersiapkan kandang kambing. Kandang sangat penting sekali sebagai pelindung panas, hujan, dingin dan tiupan angin yang sangat kencang. Kandang kambing di daerah Kelurahan Tembilahan Kota terbuat dari kayu sedangkan atapnya terbuat dari atap rumbia dan seng. Atap rumbia/nipah harganya lebih murah dan sesuai dengan keadaan perekonomian peternak tersebut. Rumbia/nipah tidak terlalu menyerap panas matahari sehingga kondisi kandang tidak terlalu panas pada siang hari dan tidak terlalu dingin pada malam hari. 
Sementara seng digunakan peternak dikarenakan tidak mudah rusak dan lebih tahan lama bila dibandingkan dengan menggunakan atap rumbia/nipah. Ukuran kandang sebagian besar berukuran 3 x $8 \mathrm{~m}$ dengan kapasitas 35 ekor. Mayoritas kambing di daerah penelitian dicampur semua dalam satu kandang dan ada juga sebagian yang dipisah berdasarkan kriteria yang kecil dan besar, karena semuanya adalah kambing jantan. Hal ini berbeda menurut (Sarwono,2007), kandang untuk pejantan dibuat khusus dengan ukuran $125 \mathrm{~cm} \times 150 \mathrm{~cm}$ per ekor atau minimal $150 \mathrm{~cm}^{2}$ luas kandang.

Model kandang yang dibuat di daerah penelitian berbentuk panggung. Menurut Sarwono (2007), model kandang untuk kambing umumnya berbentuk panggung yang dibangun diatas permukaan tanah sehingga terdapat kolong dibawah kandang.

Peternak kambing di Kelurahan Tembilahan Kota memperoleh bibit dari daerah Madura, Lampung dan Surabaya yaitu kambing kacang. Harga bibit bervariasi antara Rp. 1.445.000,00 sampai dengan Rp. 1.500.000,00 per ekor. Pemilihan bibit yaitu kambing yang sehat, berat tubuh sekitar 10 hingga $15 \mathrm{~kg}$.
Penambahan makanan penguat atau konsentrat ke dalam pakan ternak juga dapat meningkatkan palatabilitas pakan yang dikonsumsi dan pertambahan berat badan (Anggorodi, 1990). Pakan terdiri dari rumput dan ampas kedelai. Rumput merupakan makanan pokok bagi ternak kambing. Rumput diperoleh peternak dengan mencari sendiri di sekitar daerah Tembilahan dan ada juga ada dibeli dengan harga per keranjang Rp.20.000,00 dan diberi 3 kali sehari. Sedangkan ampas kedelai sisa pembuatan tahu diberikan satu minggu sekali kepada kambing. Sementara obat-obatan yaitu obat yang diberikan untuk kambing yang sakit mata yang diberikan satu keping.

Kambing dijual mayoritas telah dipelihara selama 4 bulan dengan ratarata harga jual sebesar Rp. 2.162.500,00 per ekor dengan berat tubuh 19 hingga $25 \mathrm{~kg}$. Mayoritas pembeli kambing adalah konsumen yang berasal dalam kota Tembilahan yaitu untuk acara aqiqah anak.

\section{Analisa Usaha}

Analisis usaha kambing di Kelurahan Tembilahan Kota, rincian biaya yang dikeluarkan dalam usaha ini tersaji pada tabel berikut ini

Tabel 1. Analisis Rata-rata Biaya Produksi Usaha Kambing

\begin{tabular}{|c|c|c|c|c|}
\hline No & Biaya & Unit & Harga Jual (Rp) & Total (Rp) \\
\hline \multirow[t]{5}{*}{1} & Biaya Variabel (a) & & & \\
\hline & - Bibit kambing & \multicolumn{2}{|l|}{ Ekor } & $53.906 .250,00$ \\
\hline & $\begin{array}{l}\text { Pakan } \\
\text { - Rumput }\end{array}$ & \multirow{3}{*}{\multicolumn{2}{|c|}{$\begin{array}{l}\text { Keranjang } \\
\text { Kg } \\
\text { Keping Ekor }\end{array}$}} & $15.900 .000,00$ \\
\hline & - Ampas Kedelai & & & $420.000,00$ \\
\hline & - Obat-obatan & & & $219.250,00$ \\
\hline \multirow[t]{3}{*}{2} & \multicolumn{4}{|l|}{ Biaya Tetap (b) } \\
\hline & - Penyusutan Alat & & & $259.087,73$ \\
\hline & $\begin{array}{l}\text { - Tenaga Kerja Dalam } \\
\text { Keluarga }\end{array}$ & & & $400.000,00$ \\
\hline 3 & Total Biaya $(\mathrm{c})=\mathrm{a}+\mathrm{b})$ & & & $71.104 .587,73$ \\
\hline & Produksi & & & \\
\hline 1 & Bibit kambing (d) & ekor & $2.162 .500,00$ & 36 \\
\hline 2 & Pendapatan Kotor & & & $79.475 .000,00$ \\
\hline 3 & Pendapatan Bersih & & & $8.370 .412,27$ \\
\hline 4 & Pendapatan Keluarga & & & $9.029 .500,00$ \\
\hline 5 & Efesiensi & & & 1,12 \\
\hline
\end{tabular}




\subsection{Biaya Produksi}

Biaya produksi merupakan input yang dikeluarkan oleh peternak selama kegiatan usaha berlangsung hingga menghasilkan produk. Biaya produksi dalam pengelolaan usaha kambing meliputi biaya tetap dan biaya tidak tetap.

\subsubsection{Biaya Variabel}

Biaya tidak tetap atau variabel adalah biaya yang besar kecilnya dipengaruhi oleh produksi yang diperoleh (Soekartawi, 1994). Biaya variabel pada daerah penelitian terdiri dari biaya pembelian kambing sebesar Rp. 53.906.250,00, biaya pakan sebesar Rp. 16.320.000,00 dan biaya obatobatan sebesar Rp. 219.250,00. Bibit kambing mayoritas dibeli oleh para peternak dari daerah Madura, Lampung dan Surabaya dengan harga rata-rata per ekor yaitu sebesar Rp. 1.455.625,00. Pakan terdiri dari rumput dan ampas kedelai. Rumput dibeli dengan harga per keranjang Rp.20.000,00. Sedangkan ampas kedelai sisa pembuatan tahu diberikan satu minggu sekali kepada kambing, manfaatnya yaitu untuk menambah berat kambing.

\subsubsection{Biaya Tetap}

Menurut Bambang (2006), biaya tetap adalah biaya yang relatif tetap jumlahnya, dan terus dikeluarkan walaupun produksi yang diperoleh banyak atau sedikit. Biaya tetap terdiri dari biaya penyusutan alat dan biaya tenaga kerja dalam keluarga. Komposisi terbesar yaitu pada biaya tenaga kerja dalam keluarga yaitu sebesar Rp. 400.000,00 per produksi. Sedangkan dilokasi penelitian di Kelurahan Tembilahan Kota penggunaan tenaga kerja dalam keluarga ini adalah untuk kegiatan pembersihan kandang dilakukan seminggu sekali lebih kurang
2 jam dengan upah rata-rata sebesar $\mathrm{Rp}$. 25.000,00.

Besar biaya penyusutan alat per produksi yaitu sebesar Rp. 259.087,73. Biaya penyusutan ini dari masingmasing peralatan ditentukan oleh banyaknya masing-masing alat yang digunakan dan umur ekonomisnya. Alokasi biaya tetap ini sebesarnya tidak dikeluarkan tetapi untuk menghitung analisis usaha maka biaya ini tetap dihitung.

\subsubsection{Biaya Total}

Menurut Soekartawi (1995), total biaya produksi adalah keseluruhan biaya tetap ditambah dengan biaya variabel. Tabel 6 menunjukkan bahwa rata-rata biaya tidak tetap (variabel) yaitu sebesar Rp. 70.445.500,00 per produksi sedangkan rata-rata biaya tetap yaitu sebesar Rp. 579.087,73 per produksi sehingga total biaya yang dikeluarkan dalam penelitian ini adalah rata-rata sebesar Rp. 71.104.587,73 per produksi. Dapat disimpulkan bahwa kontribusi biaya terbesar adalah pada biaya variabel, hal ini dikarenakan biaya variabel yang dikeluarkan beraneka ragam.

\subsection{Pendapatan dan Keuntungan}

Pendapatan adalah perkalian antara hasil produksi yang diperoleh dengan harga jual. Sedangkan keuntungan adalah selisih antara penerimaan dengan total biaya yang dikeluarkan (Soekartawi, 1995). Sedangkan menurut Priyanto dan Yulistiyani, 2005 pendapatan usaha ternak sangat ditentukan oleh kapasitas penjualan hasil produksi pada kurun periode tertentu. Semakin banyak penjualan, maka akan semakin besar pula pendapatan dari usaha ternak.

Tabel 1 menunjukkan bahwa pendapatan yang diperoleh dari usaha kambing di Kelurahan Tembilahan Kota adalah rata-rata sebesar Rp. 
79.475.000,00 per produksi. Pendapatan ini diperoleh dari hasil kali dari jumlah rata-rata kambing yang dimiliki oleh para peternak yaitu 36 ekor kambing dengan rata-rata harga kambing yang dijual yaitu sebesar Rp. 2.162.500,00 per ekor. Sedangkan total biaya yang dikeluarkan adalah sebesar Rp. 71.104.587,73 per produksi sehingga diperoleh keuntungan sebesar Rp. 8.370.412,27 per produksi dan diperoleh keuntungan sebesar Rp. 232.511,45 per ekor. Dapat dilihat bahwa usaha kambing di Kelurahan Tembilahan Kota mendapatkan keuntungan lebih besar, hal ini disebabkan oleh jenis biaya produksi yang dikeluarkan baik biaya tetap maupun biaya variabel lebih sedikit.

Menurut Hernanto (1989), berhasil tidaknya usaha dapat dilihat dari besarnya pendapatan yang diperoleh dalam mengelola suatu usaha. Pendapatan yang diharapkan adalah pendapatan yang bernilai positif. Bagi pengusaha analisis ini membantu mereka dalam mengukur apakah kegiatan usaha mereka pada saat ini berhasil atau tidak.

\subsection{Pendapatan Kerja Keluarga}

Menurut Tohir (1983) disamping pendapatan dan keuntungan, keberhasilan atau kesuksesan usaha dapat dilihat dari sudut ekonomi yaitu besarnya penghasilan atau pendapatan kerja keluarga. Pendapatan kerja keluarga merupakan imbalan terhadap bunga harta sendiri, upah tenaga kerja keluarga dan keuntungan usaha.

Jumlah pendapatan kerja keluarga yang diterima peternak adalah rata-rata sebesar Rp.9.029.500,00. Pendapatan kerja keluarga peternak diperoleh dari pendapatan bersih ditambah dengan upah tenaga kerja dalam keluarga dan penyusutan alat.
Dapat disimpulkan bahwa pendapatan kerja keluarga peternak di daerah penelitian cukup besar, hal ini dikarenakan peternak mayoritas menggunakan tenaga kerja dalam keluarga melakukan usaha kambing.

\subsection{Efesiensi Usaha}

Salah satu ukuran efesiensi adalah penerimaan untuk rupiah yang dikeluarkan. Analisis RCR digunakan untuk mengetahui keuntungan relatif usahatani berdasarkan perhitungan finansial, dimana RCR dapat menunjukkan besarnya penerimaan yang diperoleh dengan pengeluaran dalam satu satuan biaya (Soekartawi, 1995).

Bahwa nilai RCR yang diperoleh dalam penelitian ini adalah sebesar 1,12 yang artinya setiap Rp. 1 biaya yang dikeluarkan untuk usaha kambing akan menghasilkan pendapatan kotor sebesar Rp. 1,12 atau pendapatan bersih sebesar Rp. 0,12. Menurut Soekartawi (1994), apabila nilai RCR lebih dari satu maka dapat disimpulkan bahwa usaha kambing tersebut layak untuk diusahakan.

\section{PENUTUP}

\subsection{Kesimpulan}

1. Rata-rata pendapatan yang diperoleh adalah sebesar Rp. 79.475.000,00 per produksi, sedangkan rata-rata total biaya produksi yang dikeluarkan adalah sebesar Rp. 71.14.587,73 per produksi sehingga diperoleh keuntungan rata-rata sebesar Rp. 8.370.412,00 per produksi.

2. Nilai efesiensi yang diperoleh adalah sebesar 1,12 . setiap Rp. 1 biaya yang dikeluarkan untuk usaha kambing akan menghasilkan pendapatan kotor sebesar Rp. 1,12 atau pendapatan bersih sebesar Rp. 
0,12 . Hal ini berarti usaha kambing dalam penelitian ini efesien.

\subsection{Saran}

1. Sebaiknya peternak kambing dapat meningkatkan produksi dan mutu ternak, untuk menjaga harga dan permintaan tetap tinggi sehingga dapat meningkatkan pendapatan bagi para peternak.

2. Pemerintah sebaiknya memberikan pengembangan, pemberdayaan dan pembinaan kelembagaan kelompok ternak melalui petugas penyuluh dalam upaya meningkatkan produktifitas dan pendapatan peternak

\section{DAFTAR PUSTAKA}

Anggorodi, R. 1990. Ilmu Makanan Ternak Umum. Gramedia. Jakarta.

Bambang Prasetyo. 2006. Metode Penelitian Kuantitatif : Teori dan Aplikasi. Raja Grafindo Persada : Jakarta.

Haryanto, B, Ismeth Inounu, I. Ketut Sutema. 1997. Ketersediaan dan Kebutuhan Teknologi Produksi Kambing dan Domba. Proseding Seminar nasional Peternakan dan Veteriner. Pusat Penelitian dan Pengembangan Peternakan BPPP. Departemen Pertanian. Bogor.

Hamarong, Furiyanti. 2014. Kajian Potensi Pengembangan Ternak Kambing di Kabupaten Majene. Thesis Pascasarjana Ilmu Peternakan Universitas Hasanuddin, Makassar.

Hernanto. F. 1989. Ilmu Usahatani. PT. Penebar Swadaya. Jakarta.
Hermawan, A .2009. Penelitian Bisnis. Jakarta : PT.Grasindo

Hermanto, 1991. Permintaan input dan pasokan beras yang berisiko dan bias selektivitas: studi terhadap petani Indonesia. UMI Jakarta

Krisna, R. dan Harry. 2014. Hubungan Tingkat Kepemilikan dan Biaya Usaha

dengan Pendapatan Peternak Sapi Potong di Kabupaten Sukabumi

Provinsi Jawa Barat (Studi Korelasi). Jurnal Aplikasi Manajemen.

Middatul, S. 2010. Performans Reproduksi Ternak Kambing PE (Peranakan Etawa) di PT. Reanindo Perkasa Kenagarian Barulak Kecamatan Tanjung Baru Kabupaten Tanah Datar.

Priyanto, M.D dan Yulistiani, D. 2005. Karakteristik Peternak Domba/Kambing dengan Pemeliharaan Digembalakan/Angon dan Hubungannya dengan Tingkat Adopsi Inovasi Teknologi. Jurnal Seminar Nasional Teknologi Dan Veteriner, Bogor.

Sarwono B. 2007. Beternak Kambing Unggul. Penerbit Swadaya. Jakarta.

Sinuraya, Murthada.1998. Seri Teori Manajemen Keuangan. Jakarta. Fakultas Ekonomi UI

Soekartawi. 1994. Pembangunan Pertanian. Raja Grafindo Persada. Jakarta. 1995. Analisis Usaha Tani. Raja Grafindo Persada. Jakarta. 
Tohir, A.K. 1983. Seuntai Pengetahuan

Bina Aksara. Jakarta.

Usahatani Indonesia. Bagian I. 